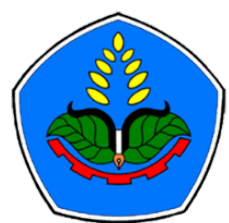

AGROPROSS

National Conference

\title{
Proceedings:
}

Peningkatan Produktivitas Pertanian Era Society 5.0 Pasca Pandemi

Tempat : Politeknik Negeri Jember

Tanggal : 22 Juli 2021

Publisher :

Agropross, National Conference Proceedings of Agriculture

ISBN : 978-623-94036-6-9

DOI : 10.25047 /agropross.2021.234

\section{Identifikasi Penyebab Penyakit Hawar Daun Bakteri Pada Kombinasi Pola Tanam System of Rice Intensification (SRI) dan Jajar Legowo}

\author{
Author(s): Rini Laraswati(1), Evan Purnama Ramdan ${ }^{(1)}$, Umi Kulsum ${ }^{(2) *}$ \\ (1) Program Studi Agroteknologi, Fakultas Teknologi Industri, Universitas Gunadarma \\ (2) Balai Besar Peramalan Organisme Pengganggu Tanaman, Jatisari, Karawang \\ * Corresponding author: umibbpopt@gmail.com
}

\begin{abstract}
Bacterial leaf blight $(H D B)$ is one of the important diseases of rice plants with yield losses reaching 15-80\%. Microclimate manipulation through cropping pattern techniques is one of the efforts to control this disease. Therefore, in this study, the cause of $H D B$ disease will be identified in a combination of system of rice intensification (SRI) and jajar legowo planting patterns. The research was conducted at the Center for Forecasting Plant Pest Organisms (BBPOPT), Jatisari, Karawang from August to September 2020. The combination of plant patterns consisted of (1) SRI with a 2:1 combination of jarwo, (2) SRI with a 3:1 combination of jarwo, (3) SRI with combination of jarwo 4:1, (4) SRI with combination of jarwo 5:1, (5) SRI without combination, and (6) system of tanem Tegal (conventional). Each tile was then divided into 5 sub-plots as replicates (1 point in each corner of the tile and 1 point in the middle of the tile). Symptoms, incidence and severity of disease were observed in each subplot. Plants showing symptoms were then identified molecularly by polymerase chain reaction (PCR) technique including total DNA extraction and nucleotide amplification using forward primer pair (F: CCTCTATGAGTCGGGAGCTG) and reverse primer (R: ACACCGTGATGCAATGAAGA). The results of the observations showed symptoms in the form of gray spots on the edges of the leaves which then developed towards the base of the leaves on one or both sides of the leaves. Subsequently the leaves become irregular and dry out. The incidence of HDB disease was 81.67 - 95\%, while the severity of the disease was 27.97 - 42.44\% in all crop patterns. Identification by PCR technique showed that the cause of HDB disease was Xanthomonas oryzae pv. oryzae amplified in the band size $230-$ $250 \mathrm{bp}$.
\end{abstract}

Keywords:

Oryza sativa;

polymerase chain reaction;

Xanthomonas oryzae pv.

oryzae

\section{Kata Kunci: ABSTRAK}

Oryza sativa;

polymerase chain reaction;

Hawar daun bakteri (HDB) merupakan salah satu penyakit penting tanaman padi dengan kehilangan hasi mencapai $15-80 \%$. Manipulasi iklim mikro melalui teknik pola tanam menjadi salah satu upaya pengendalian penyakit ini. Oleh karena itu, pada penelitian ini akan diidentifikasi penyebab penyakit HDB pada kombinasi pola tanam system of rice intensification (SRI) dan jajar legowo. Penelitian dilakukan di Balai Besar Peramalan Organisme Pengganggu Tanaman (BBPOPT), Jatisari, Karawang mulai bulan Agustus sampai September 2020. Kombinasi pola tanaman terdiri dari (1) SRI dengan kombinasi jarwo 2:1, (2) SRI dengan kombinasi

Xanthomonas jarwo 3:1, (3) SRI dengan kombinasi jarwo 4:1, (4) SRI dengan kombinasi jarwo 5:1, (5) SRI tanpa kombinasi, oryzae pv. dan (6) Sistem tanem tegal (konvensional). Setiap petak kemudian dibagi menjadi 5 subpetak sebagai ulangan (1 titik di setiap sudut petak dan 1 titik di tengah-tengah petak). Gejala, kejadian dan keparahan penyakit diamati pada masing-masing subpetak. Tanaman yang menunjukkan gejala kemudian diidentifikasi secara molekuler dengan teknik polymerase chain reaction (PCR) meliputi proses ekstraksi total DNA dan amplifikasi nukleotida dengan menggunakan pasangan primer forward (F:CCTCTATGAGTCGGGAGCTG) dan primer reverse (R: ACACCGTGATGCAATGAAGA). Hasil pengamatan menunjukkan gejala berupa bercak abu-abu di tepi daun kemudian berkembang ke arah pangkal daun baik di satu atau dua sisi daun. Selanjutnya daun menjadi tidak beraturan dan mengering. Kejadian penyakit HDB sebesar 81.67 - 95\%, sedangkan keparahan penyakit sebesar 27.97 - 42.44\% disemua pola tanaman. Identifikasi dengan teknik PCR menunjukkan bahwa penyebab penyakit HDB adalah Xanthomonas oryzae pv. oryzae yang teramplifikasi pada band ukuran 230 $250 \mathrm{bp}$. 


\section{PENDAHULUAN}

Tanaman padi merupakan salah satu tanaman pangan yang paling banyak dibudidayakan sebagai makanan pokok penduduk Indonesia (Purnamaningsih, 2006). Penurunan produksi padi di Indonesia disebabkan oleh beberapa faktor antara lain pengalihan fungsi lahan pertanian menjadi pembangunan, global warming, serta serangan hama dan penyakit. Serangan hama dan penyakit menjadi salah satu penyebab utama penurunan produksi padi akibat adanya berbagai spesies organisme pengganggu tanaman (OPT) di alam yang menyerang tanaman padi (Sembiring, 2010). Salah satu penyakit utama pada tanaman padi adalah HDB (Hawar Daun Bakteri). Penyakit ini disebabkan oleh bakteri gram negatif Xanthomonas oryzae pv. oryzae (Wahyudi, 2011). HDB di Indoneisa pertama kali dilaporkan pada tahun 1950 . Serangan HDB menyebabkan kerugian hasil panen pada musim hujan sebesar 21$29 \%$ dan pada musim kemarau $18-28 \%$. Ditahun 2010 luas penularan penyakit HDB mencapai lebih dari 110. 248 ha, 12 ha diantaranya menyebabkan puso (Suparyono, 1996; Sudir, 2012; Wahyudi, 2011). Tingkat serangan parah HDB terjadi di Jawa Barat seluas 40.486 ha, Jawa Tengah 30.029 ha, Jawa Timur 23.504 ha, Banten 3.745 ha, dan Sulawesi Tenggara 2.678 ha. karakter iklim tropis juga menyebabkan banyak ditemukanya patogen (Wening, 2016).

Penyakit HDB dapat menyerang tanaman padi baik di dataran tinggi maupun dataran rendah, namun padi dataran rendah lebih rentan. Bakteri ini menyerang tanaman padi pada stadia vegetatif dan generatif, dimana kerugian tanaman padi dapat mencapai $35 \%$ dan bila serangan mulai awal akan menyebabkan gagal panen (Triny, 2011). Bila serangan terjadi pada saat padi berbunga, maka gabah akan tidak terisi penuh atau hampa pengisian bulir tidak maksimal karena daun bendera kering, sehingga kehilangan hasil dapat mencapai $50-70 \%$. Penyakit ini sering muncul pada saat musim hujan. Antara 2006-2011 intensitas serangannya meningkat secara nyata, sehingga produksi tanaman padi menurun (Sodiq dan Mujoko,2017).

Xoo di alam mempunyai beberapa strain, tetapi dengan adanya pergeseran strain Xoo dari waktu ke waktu di persawahan. Menurut BB Padi (2015), varietas Ciherang memiliki ketahanan terhadap patotipe III dan IV penyakit HDB. Demikian juga varietas Inpari 13 pada periode tanam pertengahan, dominasi patotipe IV bergeser menjadi patotipe III. Hal ini bertepatan dengan musim hujan mulai berakhir sehingga curah hujan mulai berkurang. Menurut Asysyuura (2016), terdapat patotipe berbeda yang dapat menginfeksi varietas yang sama pada lokasi berbeda. Fase pertumbuhan dan varietas padi berpengaruh terhadap perkembangan penyakit hawar daun bakteri, semakin muda fase pertumbuhan tanaman saat terinfeksi maka semakin cepat perkembangan penyakitnya. Varietas IR64 sangat rentan terhadap penyakit hawar daun bakteri (Khaeruni et al., 2014). Balai Besar Penelitian Tanaman Padi (2015) menyebutkan bahwa bakteri patogen Xanthomonas mampu membentuk strain atau patotipe yang lebih virulen yang menyebabkan terjadinya pergeseran dominasi patogen dari waktu ke waktu sehingga ketahanan inang menjadi lebih rentan. Penelitian Yuriah et al., 2013 menyebutkan bahwa tanaman padi dengan varietas IR 64 merupakan tanaman padi yang rentan oleh bakteri Xanthomonas tipe III yang dominan di Sulawesi, Kalimantan, Jawa dan Bali.

Gejala serangan Xoo menyebabkan daun padi berubah menjadi kuning pucat, layu, dan kemudian mati (Wahyudi et al., 2011). Xanthomonas oryzae pv. oryzae (Xoo) menyerang padi pada semua fase pertumbuhan mulai dari fase persemaian 
sampai menjelang panen, menginfeksi tanaman padi pada bagian daun melalui luka daun atau lubang alami berupa stomata dan merusak klorofil daun. Kondisi ini menyebabkan kemampuan tanaman dalam fotosintesis menurun. Apabila penularan penyakit terjadi pada fase generatif maka proses pengisian gabah kurang sempurna (Puspitasari, 2014).

Untuk mengatasi masalah penyakit hawar daun bakteri dilakukan upaya pengendalian yang tepat, seperti penggunaan bakterisida kimiawi, agens hayati, kitosan dan penggunaan varietas tahan (Nisha et al., 2012; Susanto \& Sudir, 2012). Identifikasi masih diperlukan untuk mendapatkan informasi yang cepat tentang penyakit tersebut sehingga metode pengendalian yang memadai dapat di rekomendasikan (Lelliott dan Stead, 1987). Berdasarkan hal tersebut, maka sebagai langkah awal perlu dilakukan isolasi dan karakterisasi bakteri penyebab penyakit hawar daun bakteri di lahan percobaan Balai Besar Peramalan Organisme Pengganggu Tumbuhan yang mempunya sistem pola tanam System of Rice Intensification (SRI) dan jajar legowo, identifikasi tersebut dilakukan secara molekuler menggunakan PCR untuk mendapatkan gambaran tentang bakteri pathogen seperti morfologi sel dan koloni maupun karakter fisiologi dan biokimia (Schaad et al, 2001).

\section{METODOLOGI}

Penelitian ini dilakukan pada bulan Agustus hingga September 2020, di Balai Besar Peramalan Organisme Pengganggu Tumbuhan (BBPOPT) Jatisari, Karawang, Jawa Barat. Penelitian dilakukan pada lahan sawah yang memiliki sistem kombinasi pola tanam SRI dan jajar legowo. Pengamatan gejala dilakukan dengan pengamatan kenampakan secara visual di lapangan, kemudian daun yang bergejala diambil dan dilakukan identifikasi Xanthomonas oryzae pv. oryzae secara molekuler menggunakan teknik PCR (Polymerase chain reaction).

Pengamatan gejala, kejadian dan keparahan penyakit hawar daun bakteri Adapun pengamatan gejala yang dilakukan adalah:

a. Pengamatan gejala dan tanda penyakit hawar daun bakteri di lapangan secara penampakan visual pada lahan percobaan "Pengaruh Kombinasi Pola Tanam System of Rice Intensification (SRI) dan Jajar Legowo Terhadap Perkembangan OPT, dengan menggunakan metode pengamatan diagonal, 6 perlakuan, dengan setiap petak lahan yang diamati terdapat 15 sampel.

b. Perhitungan kejadian penyakit HDB menggunakan rumus sebagai berikut :

$$
\mathrm{KT}=\frac{a}{b} \mathbf{x} \mathbf{1 0 0 \%}
$$

Keterangan :

$\mathrm{KT}=$ Keterjadian penyakit

$\mathrm{a}=$ Jumlah rumpun yang terserang $\mathrm{b}=$ Jumlah rumpun yang diamati

c. Perhitungan keparahan penyakit HDB setiap minggu menggunakan rumus sebagai berikut :

$\mathrm{KP}=\frac{n \times v}{N X Z} \times 100 \%$

Keterangan:

$\mathrm{KP}=$ Keparahan Penyakit

$\mathrm{n}=$ Jumlah rumpun yang terserang dalam setiap setiap kategori serangan

$\mathrm{v}=$ Kategori (skor) serangan

$\mathrm{N}=$ Jumlah rumpun yang diamati

$\mathrm{Z}=$ Kategori (skor) tertinggi yang digunakan

\section{Isolasi Xoo dari daun bergejala}

Daun padi yang menunjukkan gejala HDB dicuci, lalu dipotong dengan ukuran $\pm 2 \mathrm{~cm}$ dan direndam dalam larutan garam 
fisiologis $0,85 \%$ selama 1 menit, kemudian dibilas menggunakan air steril selama 1menit dan keringanginkan diatas permukaan tisu, sample tersebut dipotong lebih kecil dengan ukuran sekitar $0,2 \mathrm{~cm}$ agar memudahkan untuk penanaman di cawan petri, sample disebar menggunakan metode cawan sebar pada media XA $\left(\left(\mathrm{CaCO}_{3} 30 \mathrm{~g} / \mathrm{L}\right.\right.$, glukosa $10 \mathrm{~g} / \mathrm{L}$, yeast extract $5 \mathrm{~g} / \mathrm{L}$, dan agar $15 \mathrm{~g} / \mathrm{L}$ ), saat penanaman sample, cawan petri didekatkan dengan api bunsen untuk meminimalisir terjadinya kontaminasi, kemudian lakukan pelabelan dengan informasi varietas yang digunakan, dan tanggal isolasi, serta tutup menggunakan plastik wrap.

\section{Identifikasi secara molekuler menggunakan teknik PCR}

a) Tahap Ekstraksi DNA

- Setting blok heater pada suhu $56^{\circ} \mathrm{c}$

- Ambil $200 \mu \mathrm{l}$ larutan lysozime, masukkan ke dalam collection tube 1,5 $\mathrm{ml}$

- Ambil isolat bakteri yang akan dideteksi menggunakan jarum ose, masukkan kedalam larutan lysozyme

- Homogenkan dengan vortex selama 15detik

- Lakukan sentrifugasi dengan kecepatan 7500 rpm selama 1menit

- Buang spernatant (bagian yang cair) menggunakan mikropipet

- Tambahkan buffer atl $180 \mu$ l. Homogenkan menggunakan vortex selama 30 detik

- Lakukan spin down menggunakan sentrifuge selama 1menit

- Buang spernatant (bagian yang cair) menggunakan mikropipet

- Tambahkan buffer atl $180 \mu \mathrm{l}$. Homogenkan menggunakan vortex selama 30 detik. Lakukan spin down menggunakan sentrifuge selama 1 menit.
- Tambahkan $200 \mu$ l proteinase K. Inkubasi pada suhu $56^{\circ} \mathrm{c}$ selama $1 \mathrm{jam}$, setiap 1menit divortex, lalu diinkubasi kembali

- Tambahkan $200 \mu$ l buffer AL. Homogenkan menggunakan vortex selama 15detik. Lakukan spin down menggunakan sentrifuge selama 1 menit

- Tambahkan $200 \mu$ ethanol, homogenkan menggunakan vortex selama 15detik. Lakukan spin down menggunakan sentrifuge selama 1menit. Pindahkan semua volume kedalam mini spin down. Lakukan sentrifugasi $8.000 \mathrm{rpm}$ selama 1 menit.

- Buang supernatan (cairan yang tertampung dibawah). Tambahkan

- $500 \mu \mathrm{l}$ buffer AW 1. Lakukan sentrifugasi $8.000 \mathrm{rpm}$ selama 1 menit. Buang supernatan lalu tambah $500 \mu \mathrm{l}$ buffer AW 2. Lakukan sentrifugasi $14.000 \mathrm{rpm}$ selama 3 menit

- Pindahkan spin column ke dalam collection tube yang baru. Lakukan sentrifuge $14.000 \mathrm{rpm}$ selama 1menit untuk evaporasi ethanol. Pindahkan spin column ke dalam collection tube $1,5 \mathrm{ml}$ yang baru

- Tambahkan $100 \mu \mathrm{l}$ buffer AE. Inkubasi selama 7 menit pada suhu ruang. Lakukan sentrifugasi $8.000 \mathrm{rpm}$ selama 1menit. Buang spin column. Simpan hasil elusi pada suhu $-20^{\circ} \mathrm{c}$, DNA siap diamplifikasi

b) Tahap Amplifikasi DNA

Pembuatan PCR Mix

- Siapkan loading block 0,2Ml, letakkan di atas dry ice. Ambil top taq mastermix kit dari freezer

- Cairkan top taq mastermix kit dengan cara menggosok gosokkan pada telapak tangan

- Homogenkan menggunakan vortex selama 30detik. Siapkan mikrotube $1,5 \mathrm{~mL}$ untuk membuat PCR Mix, 
letakkan pada loading block dan beri tabel.

- Campur PCR mix dalam mikrotube 1,5 $\mathrm{mL}$ sesuai dengan jumlah sampel, kecuali template DNA.

- Distirbusikan kedalammikrotube 0,2 $\mathrm{mL}$ masing masing $23 \mu \mathrm{L}$. Tambahkan $2 \mu \mathrm{L}$ template DNA kedalam masing masing mikrotube sehingga total voulem menjadi $25 \mu \mathrm{L}$.

Amplifikasi DNA pada mesin PCR

- Masukkan seluruh mikrotube pada mesin PCR

- Klik start pada program. Mesin akan mati secara otomatis ketika proses sudah selesai. Simpan hasil amplifikasi DNA pada freezer dengan suhu minimum $-20^{\circ} \mathrm{C}$. Hasil amplifikasi DNA siap untuk dielektroforesis

c) Tahap Elektroforesis

- Masukkan gel agarose 2\% kedalam tangki horizontal gel electrophoresis system. Masukkan larutan TBE 1x buffer ke dalam tangki sampai gel agarose terendam

- Siapkan selembar kertas parafilm ukuran $5 \mathrm{~cm}$ x $10 \mathrm{~cm}$. Cairkan loading dye dengan cara menggosok gosokkan pada telapak tangan

- Ambil $1 \mu$ l loading dye diatas parafilm (siapkan sebanyak sampel yang akan di loading termasuk marker dan control).

- Tambahkan $8 \mu \mathrm{l}$ DNA sampel atau marker pada loading dye

- Lakukan resuspensi menggunakan mikropipet untuk mencampur loading dye dan sampel

- Masukkan sampel yang telah diresuspensi ke dalam sumuran pada gel agarose dengan urutan marker, sampel, kontrol positif, dan kontrol negatif

- Tutup tangki elektroforesis, hubungkan dengan power supply

- Atur voltase pada 100 Volt. Atur kuat arus pada 100 ampere
- Nyalakan power supply dengan menekan tombol pada posisi "on" proses berlangsung selama 1-2jam

- Lakukan pengamatan, apabila loading dye telah mencapai separuh ukuran gel, berarti proses elektroforesis sudah selesai dan tekan tombol off.

d) Tahap Visualisasi DNA

- Tuangkan $200 \mathrm{~mL}$ larutan TBE $1 \mathrm{X}$ Buffer pada boks plastik

- Ambil larutan ethidium bromida dengan perbandingan $1 \mu \mathrm{l}: 10 \mathrm{ml}$ (Misal volume larutan TBE 1 x Buffer $100 \mathrm{~mL}$, maka larutan EtBrr yang diambil adalah $10 \mu \mathrm{l}$.

- Tuangkan larutan EtBr tersebut pada larutan TBE 1 X Buffer

- Letakkan gel agarose yang etrdiri DNA pada larutan hingga terendam

- Tutup rapat box plastik. Diamkan selama 45menit. Angkat gel dari larutan. DNA siap divisualisasi

\section{Rancangan dan analisis data}

Rancangan yang digunakan adalah Rancangan Acak Kelompok (RAK) Non faktorial, terdiri atas 6 taraf yaitu, SRI dengan kombinasi jajar legowo 2:1, SRI dengan kombinasi jajar legowo $3: 1$, SRI dengan kombinasi jajar legowo 4:1, SRI dengan kombinasi jajar legowo 5:1, SRI tanpa kombinasi, sistem tanam tegal (konvensional). Setiap unit percobaan terdiri atas 15 tanaman dan diulang sebanyak 6 kali sehingga total tanaman 90 . Adapun analisis data yang digunakan adalah sidik ragam (ANOVA) dengan menggunakan Uji Lanjut BNJ (Tukey) dengan menggunakan taraf sebesar 5\%. Perhitungan dilakukan dengan menggunakan aplikasi SAS.

\section{HASIL DAN PEMBAHASAN}

Hasil pengamatan penyakit hawar daun menunjukkan bahwa gejala yang muncul berupa bercak abu-abu pada tepi daun, bentuk tidak beraturan, kemudian 
gejala berkembang ke arah bawah daun yang meliputi kedua sisi daun dan berwarna merah keabu-abuan, kemudian daun mengering berwarna keabu-abuan, dan dapat dikenali dengan munculnya eksudat bakteri dari bekas potongan daun (Gambar 1).
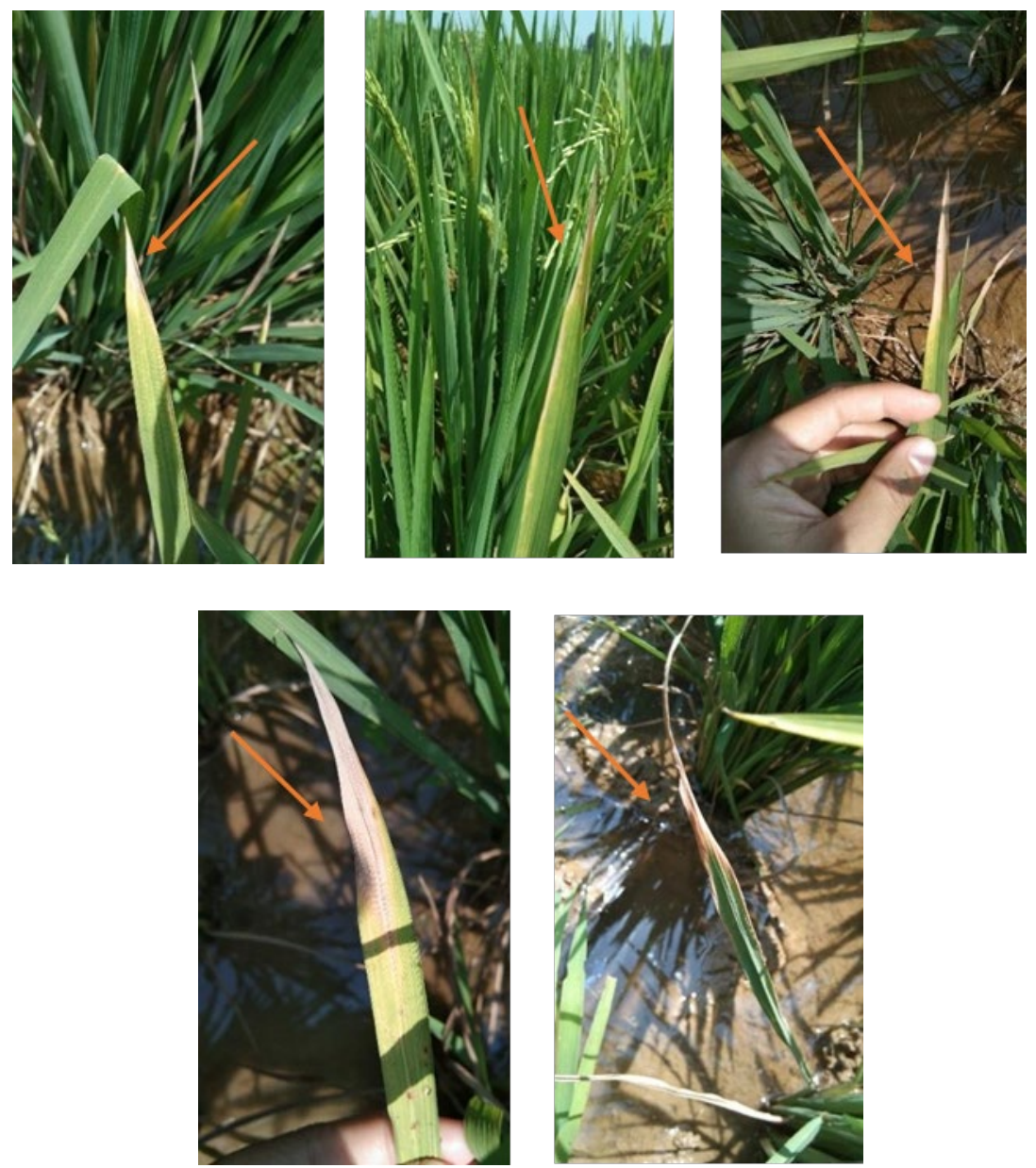

Gambar 1. Gejala penyakit hawar daun bakteri pada tanaman padi

Berdasarkan pada gambar tersebut, dapat dilihat bahwa gejala dari penyakit hawar daun bakteri adalah timbulnya bercak abu-abu pada tepi daun, bentuk tidak beraturan, kemudian gejala berkembang ke arah bawah daun yang meliputi kedua sisi daun dan berwarna merah keabu-abuan, kemudian daun mengering berwarna keabu-abuan, dan dapat dikenali dengan munculnya eksudat bakteri dari bekas potongan daun. Pada tanaman dewasa umur lebih dari 4 minggu setelah tanam, penyakit hawar daun bakteri menimbulkan gejala hawar (blight). Gejala diawali berupa bercak kebasahan berwarna keabu-abuan pada satu atau kedua sisi daun, biasanya dimulai dari pucuk daun atau beberapa sentimeter dari pucuk daun. Bercak ini kemudian berkembang meluas ke ujung dan pangkal daun dan melebar. Bagian daun yang terinfeksi berwarna hijau keabu-abuan dan agak menggulung, kemudian mengering dan berwarna abuabu keputihan. Pada tanaman yang rentan, gejala ini terus berkembang hingga seluruh daun menjadi kering dan kadang-kadang sampai pelepah. Pada pagi hari saat cuaca lembap dan berembun, eksudat bakteri 
sering keluar ke permukaan bercak berupa cairan berwarna kuning dan pada siang hari setelah kering menjadi bulatan kecil berwarna kuning. Eksudat ini merupakan kumpulan massa bakteri yang mudah jatuh dan tersebar oleh angin dan gesekan daun. Percikan air hujan menjadi pemicu penularan yang sangat efektif (Ou 1985, Mew 1989, Suparyono dan Sudir 1992).

Pengamatan gejala tidak cukup untuk memastikan penyakit pada suatu tanaman, sehingga diperlukan proses identifikasi penyebab penyakit. Sebelum mengidentifikasi, maka penyebab penyakit harus diisolasi terlebih dahulu untuk memisahkan antara bakteri penyebab HDB dengan daun padi yang terinfeksi. Hasil isolasi pada media XA $((\mathrm{CaCO} 330 \mathrm{~g} / \mathrm{L}$, glukosa $10 \mathrm{~g} / \mathrm{L}$, yeast extract $5 \mathrm{~g} / \mathrm{L}$, dan agar $15 \mathrm{~g} / \mathrm{L}$ menunjukkan bahwa ada koloni bakteri yang tumbuh (Gambar 2)

Koloni bakteri yang muncul memiliki karakteristik berbentuk bulat, cembung, berwarna kuning keputihan. Hal ini sesuai dengan pernyataan (Goto, 1990

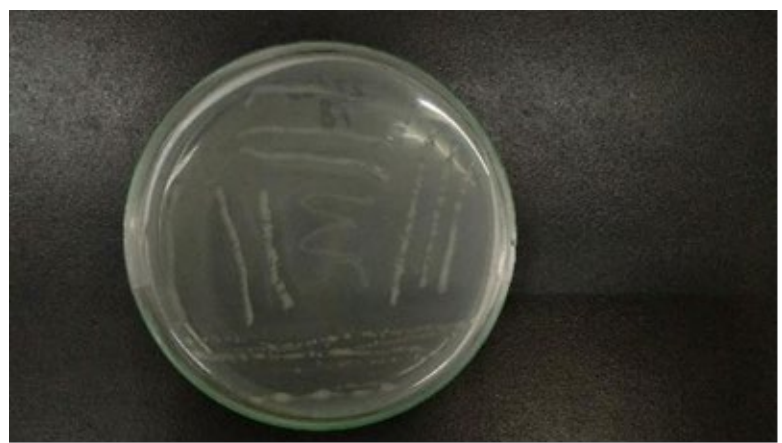

dalam Marsidah, 2002) bahwa koloni bakteri adalah bulat, cembung, berwarna kuning keputihan sampai kuning jerami dengan bagian permukaan dan tepi koloni halus dan berwarna terang. Bakteri mengeluarkan pigmen berwarna kuning yang tidak dapat dilarutkan ke dalam air (insoluble).

Setelah didapat biakan murni, kemudian isolat bakteri diremajakan pada media XA (Xanthomonas Agar) (Gambar $3)$.

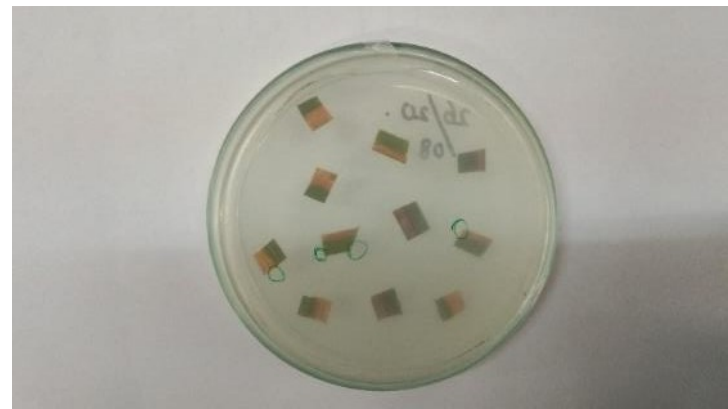

Gambar 2. Hasil isolasi bakteri Xoo

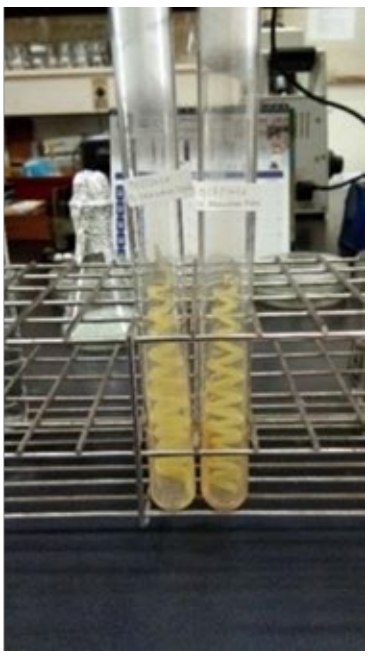




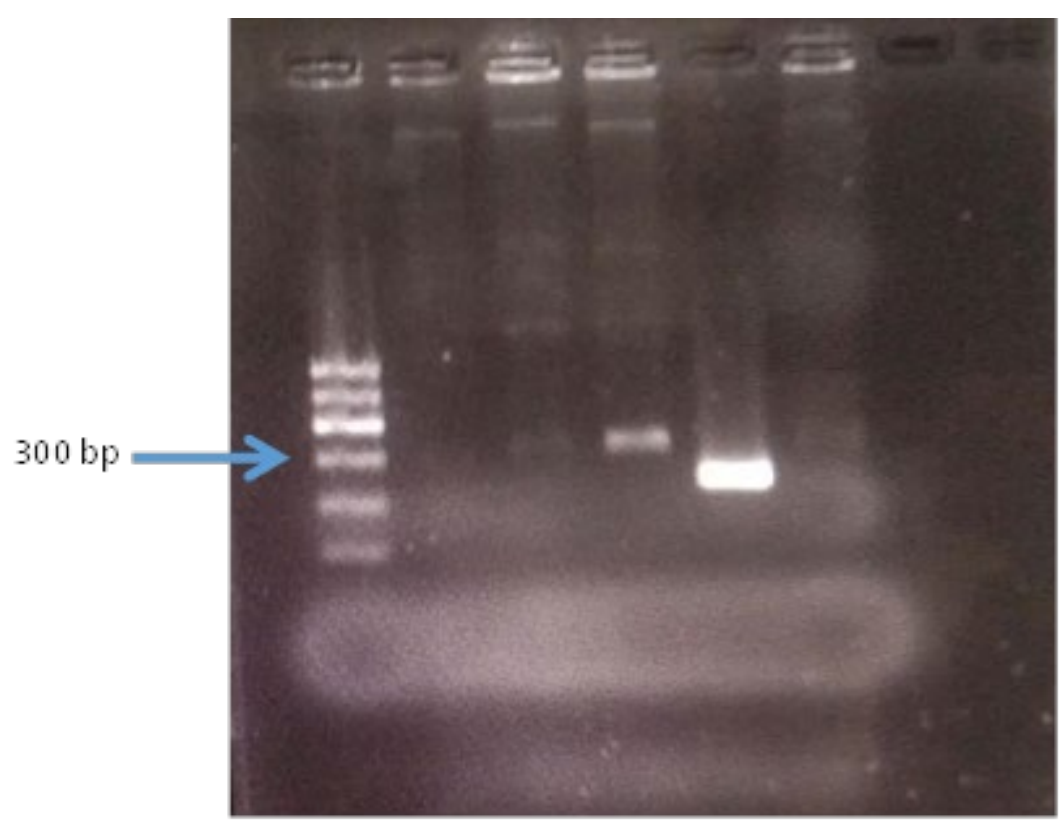

Gambar 4. Visualisasi Pita DNA Hasil Amplifikasi dengan Primer F Dan R Pada Gel Agarosa 1.5\%. M = Penanda DNA Ladder 100 Bp; 1, 2, 3,4 : Sampel Daun Padi

Sementara itu proses identifikasi penyebab HDB di BBPOPT secara molekuler dengan teknik PCR. Hasil elektroforesis yang terlihat adalah terbentuknya band yang merupakan fragmen DNA hasil amplifikasi dan menunjukkan potongan-potongan jumlah pasangan basanya. Elektroforesis menggunakan media berupa gel dari agarose ataupun akrilamid dengan pelarut menggunakan buffet Tris Asetat EDTA (TAE) atau Tris Borat EDTA (TBE). Gel dibuat dengan melarutkan agarose atau akrilamid dengan salah satu buffer tersebut dengan menggunakan cetakan khusus dan terdapat sumuran/ whell untuk menempatkan hasil PCR yang akan dirunning elektroforesis.

Hasil uji molekuler dengan teknik PCR menunjukkan bahwa DNA dari bakteri penyebab HDB teramplifikasi pada marker ukuran $200-300$, sehingga dapat dikonfirmasi bahwa penyebab penyakit HDB adalah positif Xanthomonas oryzae pv. oryzae (Gambar 4).

\section{KESIMPULAN}

Berdasarkan hasil dan pembahasan tersebut, dapat disimpulkan bahwa gejala penyakit hawar daun bakteri pada tanaman padi di lapangan yaitu timbulnya bercak abu-abu pada tepi daun, bentuk tidak beraturan, kemudian gejala berkembang ke arah bawah daun yang meliputi kedua sisi daun dan berwarna merah keabu-abuan. Selanjutnya daun akan mengering berwarna keabu-abuan dan dapat dikenali dengan munculnya eksudat bakteri dari bekas potongan daun. Hasil isolasi menunjukkan bahwa Xoo dapat tumbuh pada media XA dengan koloni berbentuk cembung, berwarna kuning keputihan. Pada proses identifikasi secara molekuler menggunakan teknik PCR, Xoo teramplifikasi pada band ukuran 230-250 bp.

\section{UCAPAN TERIMAKASIH}

Penulis mengucapkan terimakasih kepada Ibu Ani Widarti, S. Si., M.Si selaku staff Laboratorium PCR BBPOPT yang telah membantu dalam proses pengujian identifikasi Xoo secara molekuler. 


\section{DAFTAR PUSTAKA}

Asysyuura. (2016). Keragaman patotipe Xanthomonas oryzae pv. oryzae pada tanaman padi di beberapa kabupaten di Sulawesi Selatan. Tesis. Sekolah Pascasarjana. Institut Pertanian Bogor. Bogor. 53 hlm.

Balai Besar Penelitian Tanaman Padi (2015) Hawar Daun bakteri (HDB) dan cara Pengendaliannya. Badan Penelitian dan Pengembangan Pertanian. Subang

BB Padi. 2015. Deskripsi varietas unggul baru padi. Badan Penelitian dan Pengembangan Pertanian. Kementerian Pertanian. $77 \mathrm{hlm}$.

Khaeruni, A., M. Taufik, T. Wijayanto, E.A. Johan. 2014. Perkembangan penyakit hawar daun bakteri pada tiga varietas padi sawah yang diinokulasi pada beberapa fase pertumbuhan. Jurnal Fitopatologi Indonesia 10(4): 119-125

Nisha, S., Revathi, K., Chandrasekaran, R., Kirubakaran, SA., SathishNarayanan, S., Stout, MJ., dan Senthil Nathan S. 2012. Pengaruh Senyawa Tanaman Pada Aktivitas Yang Diinduksi Enzim Terkait Pertahanan Dan Protein Terkait Patogenesis Pada Tanaman Padi Yang Rentan Penyakit Hawar Bakteri . Physiol. Mol. Tanaman Pathol. 80: 1-9.

Ogawa T, Busto GA, Tabien RE, \& Khush GS. 1988. Further study of Xa-4b gene for resistance to bacterial blight of rice. Rice Genetics Newsletter 5: 104-105.

Ou, S.H. 1985. Rice Disease. Commonwealth. Inst. Kiew, Surrey, England. 368 p.

Purnamaningsih, R. 2006. Induksi Kalus dan Optimasi Regenerasi Empat Varietas Padi Melalui Kultur In Vitro. Jurnal Agrobiogen, 2(2):7480.

Puspitasari, Monita. 2014. Diskripsi Sifat
Khas Bakteri Xanthomonas oryzae pv. oryzae. Program Pasca Sarjana, Program Studi Hama dan Penyakit Tumbuhan Universitas Andalas, Padang.

Sembiring, H. 2010. Kesiapan Teknologi Budidaya Padi Menanggulangi Dampak Perubahan Iklim Global. Prosiding Seminar Ilmiah Hasil Penelitian Padi Nasional 2010 (Buku 1). Balai Besar Penelitian Tanaman Padi

Sodiq, M. dan Mudjoko, T. (2019). Pengendalian Terpadu Hama dan Penyakit Tanaman Padi. Plantaxia, Graha Ilmu. 120hlm.

Sudir, Nuryanto B, \& Kadir TS. 2012. Epidemiologi, patotipe, dan strategi pengendalian penyakit hawar daun bakteri pada tanaman padi. Iptek Tanaman Pangan 7(2): 79-87.

Suparyono dan Sudir., 1992. Perkembangan penyakit bakteri hawar daun pada stadia tumbuh yang berbeda dan pengaruhnya terhadap hasil padi. Media Penelitian Sukamandi, 12, pp. 6-9.

Triny, S.K. 2011. Penyakit hawar daun bakteri dalam tonggak kemajuan teknologi produksi tanaman pangan. Bogor: Paket dan Komponen Teknologi Produksi Padi

Wahyudi AT, Meliah S, \& Nawangsih AA. 2011. Xanthomonas oryzae pv. oryzae bakteri penyebab hawar daun pada padi: isolasi, karakterisasi, dan telaah mutagenesis dengan transposon. Makara Sains 15(1): 8996.

Wening, R. H., susanto, U. dan Satoto. 2016. Varietas unggul padi tahan hawar daun bakteri: perakitan dan penyebaran di sentra produksi. Iptek tanman pangan. 11 (2).

Yuliani, D., A. Faizal, dan Sudir. (2012). Identifikasi patotipe Xanthomonas oryzae pv. oryzae, penyebab hawar daun bakteri padi di daerah sentra 
produksi adi di Provinsi Sulawesi

Selatan. Prosiding Seminar Nasional

Hasil Penelitian Tanaman Padi 2011.

p.121-130.

Yuriah S, Dwinita W, Utami \& Hanarida I (2013) Uji Ketahanan Galur-galur Harapan Padi terhadap Penyakit Hawar Daun Bakteri (Xanthomonas oryzae pv. oryzae) Ras III, IV, dan VIII. Balai Besar Penelitian dan Pengembangan Bioteknologi dan Sumber Daya Genetik Pertanian. Buletin Plasma Nutfah Bogor 19 (2). 